4. Filipová, M., \& Rampley, M. (Eds.). (2007). Možnosti vizuálních studii: obrazy, texty, interpretace. Společnost pro odbornou literaturu-Barrister \& Principal.

5. Freedberg, D. (1989). The power of images: Studies in the history and theory of response Chicago: University of Chicago Press.

6. Freedberg, David. Holy images and other images, URL:http://www.columbia.edu/cu/arthistory/faculty/Freedberg/Holy-ImagesOther-Images.pdf

7. Garnett, J., \& Rosser, G. (2013). Spectacular miracles: Transforming images in Italy from the Renaissance to the present. Reaction Books.

8. Graham, H. (2006). The art of the sacred: an introduction to the aesthetics of art and belief. IB Tauris.

9. Mirzoeff, N. (2009). An Introduction to Visual Culture (2d ed.). London\&New York.

10. Mitchell W.T.J. (2005). What Do Pictures Want? (The Lives and Loves of Images). Chicago

11. Plate, S. B. (2002). Religion, art, and visual culture: a cross-cultural reader. Palgrave.

12. Rampley, M. (2005). Exploring visual culture: Definitions, concepts, contexts. Edinburgh University Press.

DOI https://doi.org/10.30525/978-9934-26-004-9-10

\title{
МИСТЕЦТВО АНІМАЦІЇ У ЦИФРОВУ ЕПОХУ
}

\author{
Мараховська К. Д. \\ аспірантка кафедри мистецтввознавства \\ та загальногуманітарних дисииплін \\ Міжнародного гуманітарного університету \\ м. Одеса, Україна
}

Анімаційне мистецтво розвивається і трансформується під впливом загальнокультурних та технологічних змін. Удосконалюються технічні можливості, змінюються виражальні засоби, формується нова естетика.

3 появою сучасних цифрових технологій функціонування анімації у культурному просторі набуло нових форм. Анімація перетворилась на загальновживаний елемент у багатьох сферах. Спостерігається іiі використання у більш широкому контексті - від рекламної продукції до бізнес презентації. 
Незважаючи на спільне коріння 3 комп'ютерною графікою i використовуючи подібні способи і технології створення цифрового зображення, анімація комп'ютерна має свою специфіку, «оживлюючи» статичні віртуальні моделі надаючи їм руху та дії. На відмінну від технології створення анімаційного образу у минулому (класичним мальованим способом), завдяки комп'ютерним технологіям мальовані образи, або лялькова анімація замінені цифровими моделями.

Також відбуваються зміни у створенні цифрового анімаційного образу. Сьогодні програмне забезпечення дає можливість змінювати будь-які частини анімаційного кадру, від положення камери, до зміни образу героїв і навіть атмосфери. Завдяки програмному забезпеченню відбувається зміна виражальних можливостей анімаційного мистецтва. По суті «створюється нова гібридна естетика» [1, с. 334].

Цифрові технології не тільки вплинули на технічні можливості створення цього виду аудіовізуальної культури, а й спричинили появу нового напрямку net-анімації. Net-анімація (або Мережева анімація), існує вже не у вербальних знаках, а у багатогранній мультимедійній формі. Вона $\epsilon$ «принципово новою демократичною областю постцифрової культури» [1, с. 336]. По-перше, це проявляється в тому, що будь-хто, має доступ до Мережі, може створювати і розміщувати анімацію без узгодження 3 будь-якою цензурою. Потрібно лише володіння базовими технічними навичками та вміння користуватись програмами. Це, у кінцевому результаті, призводить до розмивання професії «художника-аніматора», перетворює іiі у хобі, розвагу. I як результат - зниження художнього рівня твору. Про це досить точно висловилась дослідниця Н. Кривуля: «Масовість завжди передбачає спрощеність - і технологічну, і смакову. Все це можна спостерігати на прикладі сучасної мережевої анімації, яка виникла як новий вид аудіовізуальної сфери» [1, 367]. Частіше за все автори компенсують відсутність художньої освіти технічними складовими. Цей той випадок, коли технологія намагається стати мистецтвом, і професіоналами можуть стати лише ті, які не тільки володіють комп'ютерними програмами, а й мають можливість творити нове, що буде мати більш високий естетичний рівень. Як правило, вони несуть в собі дещо несерйозне, іронічне, «прикольне». Через що, у більшості виникає хибне уявлення про технічну простоту виконання ідеї.

По-друге, Мережева анімація перебуває в нерегламентованому середовищі та $\epsilon$ доступною у будь-якому куточку світу у будь-який час.

По-третє, для перегляду не потрібні спеціальні приміщення, чи інші демонстраційні потужності. Та і саме існування глядача для net-анімації 
не має такого важливого та принципового значення, як для анімації традиційної. Мережева анімація актуалізує себе, як «особливий соціальний проект < ..> новий статус анімації перетворює іiї із мистецтва у засіб репрезентації та засіб комунікації» $[1,385]$.

Сучасну мережеву анімацію поділяють на декілька форм i видів в залежності від типу технології (gif-анімація, flash-анімація, 3D-анімація і т.д.).

Однією із найбільш розповсюджених сьогодні програм, яка використовується для мережевої анімації - $\epsilon$ Flash. Маленькі розміри файлів на основі векторної графіки, простота розповсюдження зробили іiі ідеальним інструментом для створення анімації. Прикладом може бути такий мережевий проект як «Масяня» Олега Куваєва, «Кіт Саймон» Саймона Тофілда, політичні ролики студії JibJab.com тощо.

Мистецтво анімації стає залежним від технічних новацій, від віртуозності програмування, і в більшості випадків наявність спецефектів підмінює собою зміст. Таким чином, на нашу думку, втрачається художня цінність та створюється загроза художній якості. Окрім того, виникнення різноманітних фестивалів net-арт та flech-анімації, також фіксує їх інтеграцію в контекст ідейно-художнього процесу, де вона перестає бути експериментальною областю в аудіовізуальної сфери, а декларативно позиціонує себе, як новий напрямок мистецтва. Якщо раніше це був достатньо замкнутий світ, який відомий був фанатам окремих напрямків, або випадковим відвідувачам Мережі, то тепер netанімація фіксує свій статус у загальній динаміці сучасного мистецтва. А отже, функціонування анімації у цифрову епоху потребує подальшого наукового осмислення. Дослідження ії художніх можливостей та нової екранної образності ще попереду.

\section{Література:}

1. Кривуля Н. «Интернет и сетевая анимация», Экранная культура. Теоретические проблемы / Отв. ред. К. Э. Разлогов. - СПб.: «ДМИТРИЙ БУЛАНИН», 2012. - 752 с. 